\title{
Diversity and traditional knowledge of medicinal plants in home gardens of Kampung Masjid Ijok, Perak, Malaysia
}

\author{
MOHD RAZNAN RAMLI ${ }^{1, \boldsymbol{\nu}}$, POZI MILOW ${ }^{1}$, SORAYYA MALEK ${ }^{2}$ \\ ${ }^{1}$ Department of Environmental Management, Faculty of Science, Institute of Biological Sciences, University of Malaya, Kuala Lumpur, Malaysia. Tel.: \\ +603-79676777, ^email: raznan83@gmail.com \\ ${ }^{2}$ Bioinformatics Faculty of Science, Institute of Biological Sciences, University of Malaya, Kuala Lumpur, Malaysia
}

Manuscript received: 17 March 2021. Revision accepted: 3 April 2021.

\begin{abstract}
Ramli MR, Milow P, Malek S. 2021. Diversity and traditional knowledge of medicinal plants in home gardens of Kampung Masjid Ijok, Perak, Malaysia. Biodiversitas 22: 2458-2465. Medicinal plants and associated traditional knowledge are at risk of habitat modification, globalization, urbanization, and modernization. Though home gardens are recognized as a potential strategy for medicinal plant conservation, at the same time very limited efforts have been made for the documentation of ethnomedicinal plants. We explored and documented the diversity and population status of ethnomedicinal plants in the home gardens of Kampung Masjid Ijok along with its associated traditional knowledge. Field observation and semi-structured interviews were conducted to record for the medicinal uses of the medicinal plants in the home gardens. The information, i.e. local name, parts used, methods of preparation, and type of ailments, were also collected. The total numbers of medicinal plants recorded in the study area were 68 species belonging to 40 families. The families of Zingiberaceae, Asteraceae, Acanthaceae, and Fabaceae were recorded as having the highest number of medicinal plants. Herbs were the main source of medicinal plants in terms of species number followed by shrubs, trees, and climbers. Cocos nucifera L, Carica papaya L, Areca catechu L, and Citrus aurantiifolia (Chris. \& Panz.) Swin were the most frequent species of medicinal plants. Shannon diversity index of medicinal plant species was 3.7. The most frequently utilized plant parts were the leaves followed by roots, fruits, rhizomes, whole plants, flowers, seeds, and barks. Gastrointestinal disorders including stomach ache, diarrhea, dysentery, indigestion, flatulence, worm infestation in children, and constipation were among the most frequent ailments treated with the medicinal plants. This study revealed that many medicinal plants are still broadly found in home gardens and used for treating various ailments. The information recorded in this study may form the basis for the conservation and sustainable use of ethnomedicinal plants and may also contribute to the preservation of cultural and genetic diversity.
\end{abstract}

Keywords: Diversity, home gardens, Kampung Masjid Ijok, medicine plants, traditional knowledge

\section{INTRODUCTION}

Malaysia's tropical forests are recognized as a hub for biodiversity, where a large number of medicinal plants are recorded which constitute an enormous potential source of plant-derived chemicals that are useful to humans. Almost 15,000 species of flowering plants have already been identified in the rainforests of Malaysia, and many more have not been identified and documented yet (Hussain et al. 2015). About 20 percent of these 15,000 flowering plants were documented as being used as traditional medicines by local communities mainly by the Malays, including the Orang Asli (Hussain et al. 2015). Azliza et al. (2012) reported that the Orang Asli of Ulu Kuang village in the state of Selangor used 49 species of medicinal plants. Zaki et al. (2019) recorded that the Orang Asli community in the state of Kelantan used 18 species of medicinal plants. Mohammad et al. (2012) recorded 39 species of medicinal plants were used for treating various ailments by the Orang Asli in Kampung Ulu Legong in the state of Kedah. Ong et al. (2012) indicated that the Orang Asli community in Kampung Pos Penderas in the state of Pahang used 53 species of medicinal plants. Ong et al. (2011a) recorded 56 medicinal plant used by the Malay community in Kampung Mak Kemas in the state of Terengganu.
Medicinal plants and associated traditional knowledge are at risk of habitat modification, globalization, urbanization, and modernization. According to SaynesVasquez et al. (2013), the main factors leading to the loss of traditional knowledge of medicinal plants were the presence of modern public healthcare, economic development, and current systems of formal education. The study by $\mathrm{Hu}$ et al. (2020) among the Mulam community in Guangxi, China indicated that the lack of written records, conservative inheritance patterns, rapid economic development, and low interest in traditional medicinal knowledge among young people were the factors that contributed to the loss on the traditional knowledge. Moreover, some medicinal plants are threatened with extinction from overharvesting and habitat destruction with the increasing human population and plant consumption. According to Pimm et al. (1995), the current loss of plant species is between 100 and 1000 times higher than the expected natural extinction rate, and that the Earth is losing at least one potential major drug source every two years.

Therefore, the role of local communities in the conservation, management, and utilization of medicinal plants should be recognized. A possible strategy for the conservation of medicinal plants is cultivation in the home gardens. Home gardens are less complex agroforests, 
almost similar to natural forest ecosystems, and integrated into agricultural management systems located around houses (Mapongmetsem et al. 2012). According to Gao et al. (2012), medicinal plants in the home gardens are either intentionally cultivated or spontaneously grown as wild or weed species. Panyadee et al. (2019) indicated that there were 95 species of medicinal plants recorded in home gardens of four ethnic groups in Thailand. Pala et al. (2019) recorded 53 species of medicinal plants in home gardens of the Eastern Himalaya. Huai et al. (2011) reported that home gardens have been an important site for domestication of medicinal and fruit plants which constitute an important contribution to the conservation of rare, endangered, or over-exploited species. Though home gardens are recognized as a potential strategy for medicinal plant conservation, very limited efforts have been made for the documentation of ethnomedicinal plants. We explored and documented the diversity and population status of ethnomedicinal plants in the home gardens of Kampung Masjid Ijok along with its associated traditional knowledge. The information and data generated in this study may form the basis for the conservation and sustainable use of ethnomedicinal plants and may also contribute to the preservation of cultural and genetic diversity.

\section{MATERIALS AND METHODS}

The present study was carried in the village of Kampung Masjid Ijok, Selama district in the state of Perak, Malaysia (Figure 1).

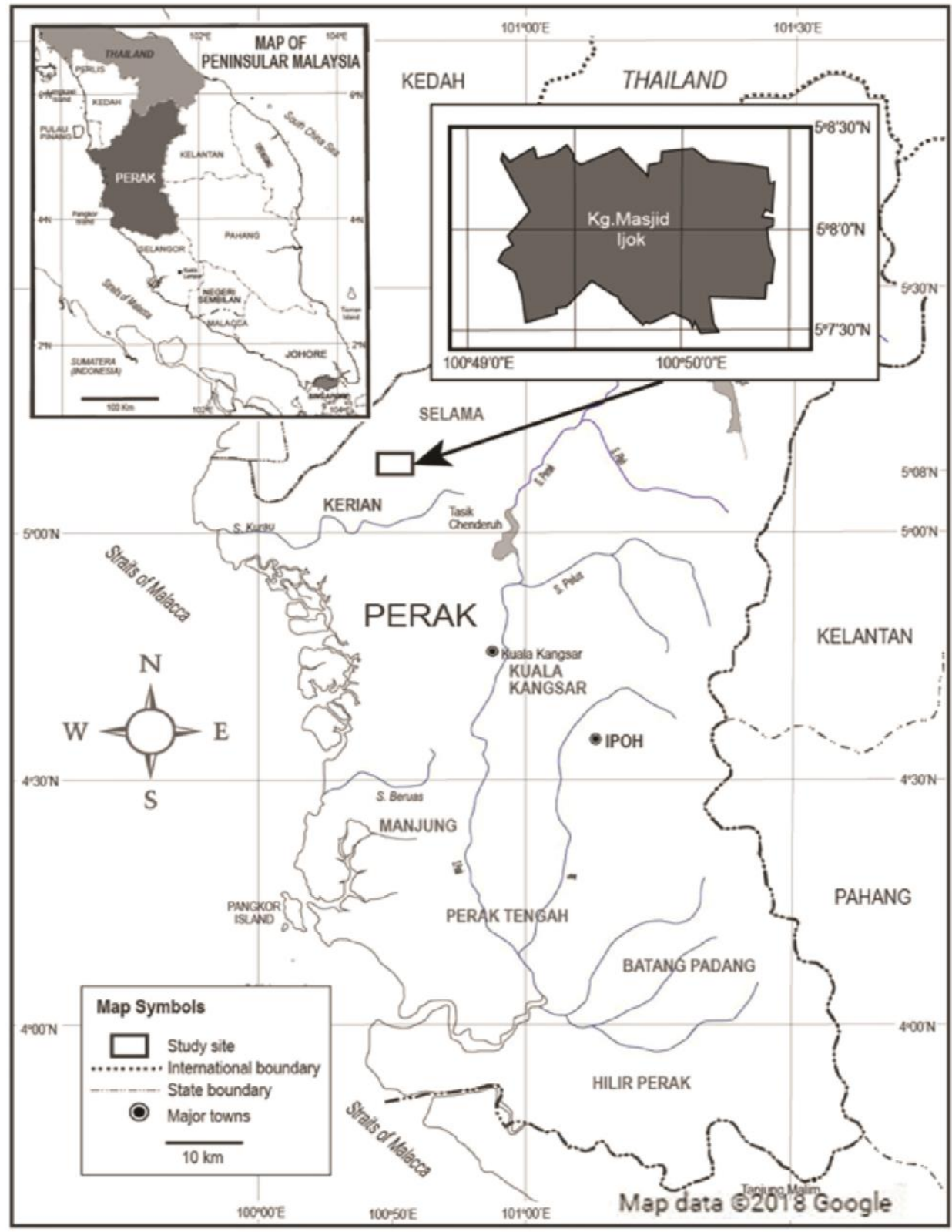

Figure 1. Study area in Village of Kampung Masjid Ijok, Selama District, State of Perak, Malaysia 
The village is located between $5^{0} 7^{\prime} 0^{\prime \prime} \mathrm{N}$ to $5^{0} 8^{\prime} 15^{\prime \prime}$ latitude and $100^{\circ} 49^{\prime} 15^{\prime \prime} \mathrm{E}$ to $100^{\circ} 50^{\prime} 45^{\prime \prime} \mathrm{E}$ longitude with an average altitude of 50 meters above sea level. Kampung Masjid Ijok is characterized by a tropical climate with temperatures recorded from $28^{\circ} \mathrm{C}$ to $32^{\circ} \mathrm{C}$ throughout the year, and 2,000 $\mathrm{mm}$ to $2,500 \mathrm{~mm}$ of annual precipitation. The population consists of 200 inhabitants belonging to 60 households and is only composed of the Malays. The economy is agriculture-based, rubber tree and palm oil are the major crops. The major occupation of the local people is farming. The villagers also depend heavily on home gardens for their daily needs, especially for day-to-day dietary and health supplements. Field observation in 40 home gardens and semi-structured interviews were used to gather information on traditional knowledge of medicinal plants regarding their uses, parts used, and mode of preparation. Photographs of each medicinal plant were taken for identification purposes and documentation. For each home garden, the numbers of individuals for each medicinal plant were recorded to determine frequency and Shannon-Wiener diversity index. The index is determined using the following formula:

Frequency $=\frac{\text { No. of homegardens in which a species occurs }}{\text { Total no. of homegardens }}$
$\mathrm{H}=\sum_{\mathrm{i}=1}-\left(\mathrm{P}_{\mathrm{i}} * \ln \mathrm{P}_{\mathrm{i}}\right)$
Where:
$\mathrm{H}:$ the Shannon-Wiener diversity index
$\mathrm{P}_{\mathrm{i}}$ : fraction of the entire population made up of species $\mathrm{i}$
$\mathrm{S}:$ numbers of species encountered
$\sum$ : sum from species 1 to species $\mathrm{S}$

\section{RESULTS AND DISCUSSIONS}

In the present study, a total of 68 plant species were recorded in 40 home gardens of Kampung Masjid Ijok belonging to 65 genera and 40 plant families (Table 1). The total species recorded in this study is higher compared to other Malays village in Terengganu and Negeri Sembilan. Ong et al. (2011a) reported that the Malays of Kampung Mak Kemas, Terengganu used 56 species of medicinal plants. Ong et al. (2011b) noted that the Malay in the Kampung Tanjung Sabtu, Terengganu used 52 species of medicinal plants. Aziz and Zakaria (2013) recorded 50 species of medicinal plants in Lenggong Valley, Perak. Compared to other native communities in Peninsular Malaysia, the overall species recorded in this study are also considered to be higher. Ramli et al. (2021) indicated that the Temuan community of Kampung Orang Asli Donglai Baru, Selangor used 39 species of medicinal plants in the treatment of various ailments. Temuan community in Kampung Ulu Kuang, Selangor used 49 species of medicinal plants (Azliza et al. 2012). In the village of Johor, Sabran et al. (2016) recorded 23 species of medicinal plants used by the Jakun community. Temiar community in the village of Kelantan only used 18 species of medicinal plants (Zaki et al. 2019). Jah Hut community in Kampung Pos Penderas, Pahang used 53 medicinal plants (Ong et al. 2012a). Semai community in Kampung Batu 16, Perak used 37 species of medicinal plants (Ong et al. 2012b). A report by Milow et al. (2013) indicated that 28 species of medicinal plants were recorded in the Orang Asli home gardens in Negeri Sembilan. Mohammad et al. (2012) recorded 35 species of medicinal plants used by the Kensiu community in Kampung Lubuk Ulu Legong, Kedah. The high species of medicinal plants recorded in this study demonstrates the importance of home gardens as a repository of ethnomedicinal knowledge of the Malays community in Kampung Masjid Ijok. The differences in the total of medicinal plants recorded in other studies could be the result of different cultural or environmental factors. According to Quave and Pieroni (2015), the traditional knowledge of medicinal plants from different ethnic groups is restricted by cultural boundaries. Some plants are not only considered to have medicinal value by some ethnic groups, but also considered weeds by other ethnic groups, and vice versa.

The largest proportion of medicinal plants belonged to the families of Zingiberaceae (6 species), followed by Asteraceae (5 species), Acanthaceae (3 species), and Fabaceae ( 3 species). The present study is in line with other studies in Malays villages. Ong et al (2011a) indicated that Zingiberaceae, Euphorbiaceae, Acanthaceae, Lamiaceae, Piperaceae, and Poaceae were among the most common plant families in the Kampung Mak Kemas, Terengganu. Ong et al. (2011b) reported that Zingiberaceae and Poaceae were among the most plant families in the Kampung Tanjung Sabtu, Terengganu followed by Acanthaceae, Piperaceae, Rutaceae, and Solanaceae. In comparison to the Orang Asli community, Zingiberaceae is also recorded as the most common plant families. Among the Kensiu communities in Kampung Lubuk Ulu Legong, Mohammad et al. (2012) indicated that Zingiberaceae, Asparagaceae, Rubiaceae, and Sapindaceae were among the highest plant families of medicinal plants. The same pattern were also recorded by Ramli et al. (2021), Zaki et al. (2019), and Azliza et al. (2012) who observed that Zingiberaceae was the highest plant family used by Orang Asli in Kampung Donglai Baru Selangor, Kampung Pasik Kelantan, and Kampung Ulu Kuang Selangor respectively. This demonstrates that Zingiberaceae is the most common family of medicinal plants used by the Malays and Orang Asli communities in Peninsular Malaysia. The recognition of the medicinal properties of plants in the Zingiberaceae family is also common among many ethnic groups in other regions. In Thailand, the Karen which is the largest ethnic minority in the country cultivated many medicinal Zingiberaceae in their home gardens (Tangjitman et al. 2015). In Indonesia, Jadid et al. (2020) reported that the Zingiberaceae was the most abundant of plant family used by the Tengger tribe in the Ngadisari village.

Herbs were the main life-form of medicinal plants in terms of number of species (27 species), followed by shrubs (20 species), trees (19 species), and climbers (2 
species) as shown in Figure 2. Cocos nucifera L, Carica papaya L, Areca catechu L, and Citrus aurantiifolia (Chris. \& Panz.) Swin were the most frequent species. Bhat et al. (2014) also notified that coconut palm is the most dominant species in the home gardens of Karwar, India. According to Cruz-Garcia and Struik (2015), most of the plant species in home gardens were selected according to their owners' preferences. In this study, home gardens also function as experimental nurseries for propagating and domesticating some species from nearby forests. The best examples of this are Eurycoma longifolia Jack, Garcinia atroviridis Griff. ex T. Anders, Nepenthes gracilis Korth, Parkia speciosa Hassk, Scorodocarpus borneensis (Baill.) Becc, Vitex pubescens Vahl, and Zingiber aromaticum Vahl, which now, according to the local informants, are very rare in the forest because of land conversion to rubber tree and palm oil plantation. As a result, many villagers began to cultivate them for self-consumption in their home gardens and sometimes sold them to the nearest market as additional income. This finding is also in line with Eyasu et al. (2020) which noted that home gardens were an important reservoir of native plant species that were endangered or over-exploited in the forests near the villages. Some plants grow spontaneously in the home gardens and are not removed but protected by attaching them to a solid structure, or by laying stones around the plants. Such examples include Oxalis barrelieri L., Phyllanthus pulcher Wall. ex Müll. Arg, Stachytarpheta jamaicensis (L.) Vahl, and Tacca integrifolia Ker Gawler.

The total number of medicinal plant species per home garden ranged from 4 to 20 with a mean of $5.43 \pm 5.10$ with Shannon-Wiener Index 3.7. Shannon-Wiener Index in this present study corresponds with the value recorded in home gardens of Bangladesh (Rahman et al. 2013) and Sri Lanka (Mattsson et al. 2015) with ranges from 3.0 to 4.0. The index value recorded in this study is higher compared to the study in Sudan (Wiehle et al. 2014), and Ethiopia (Abebe et al. 2013) with the values recorded were 1.46 and 1.41 respectively. However, the study is lower compared to the study by Srithi et al. (2012) in home gardens of Northern Thailand with the Shannon-Wiener diversity index varied from 4.56 to 5.06. The finding of this study indicated that the home gardens of Kampung Masjid Ijok is rich with medicinal plant species and need to be considered for in situ conservation. Wezel and Ohl (2005) reported that about $55 \%$ of the medicinal plants that were noted in their study in the Amazon region were found in only one single home garden. The difficulty to get modern medicine in rural areas is also a main factor of the home gardens owners to use the plants as an alternative medicine to treat certain ailments. The plant parts used for medicinal preparations were leaves, roots, flowers, fruits, rhizomes, and in some cases the whole plants including the roots. The most frequently plant parts were the leaves (41\%), followed by roots $(26 \%)$, fruit $(15 \%)$, rhizome $(9 \%)$, whole plants $(6 \%)$, flowers $(1 \%)$, seed $(1 \%)$, and bark $(1 \%)$ as shown in Figure 3. Leaves were the most frequently part plant used in this study which is similar to the report on other villages by Ong et al (2011b). This practice can be a sustainable way to exploit medicinal plants compared to harvesting of other plant parts and helps to reduce the rate of threat on plant species and subsequently conserve the medicinal plants.

Gastrointestinal disorders including stomach ache, diarrhea, dysentery, indigestion, flatulence, worm infestation in children, and constipation are among the most frequent ailments treated with medicinal plants $(25 \%$ of all remedies). Then, the ailments are followed by respiratory problems, women-related health, hypertension, diabetes, fever, headache, and kidney stones. The most commonly used plant species in the treatment of gastrointestinal disorders include Carica papaya L, Clinacanthus nutans (Burm F.) Lindau, Coleus blumei Benth, Psidium guajava L, Scorodocarpus borneensis (Baill.) Becc, Zingiber officinale Roscoe, and Zingiber aromaticum Vahl. Psidium guajava L was also cited by other ethnobotanical studies in other locations in Malaysia to treat diarrhea and stomach-ache. For example, Ong et al. (2012a) reported the use of Psidium guajava to treat diarrhea and stomach-ache among the Orang Asli community in Kampung Pos Penderas, Pahang. Ramli et al. (2021) also reported that the Orang Asli community in Kampung Donglai Baru, Selangor also used Psidium guajava $\mathrm{L}$ to treat the same ailments.

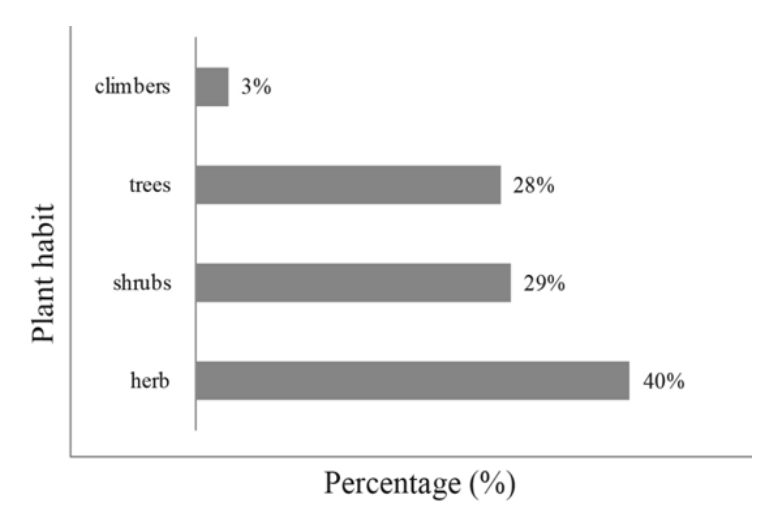

Figure 2. Diversity of life-form of medicinal plants

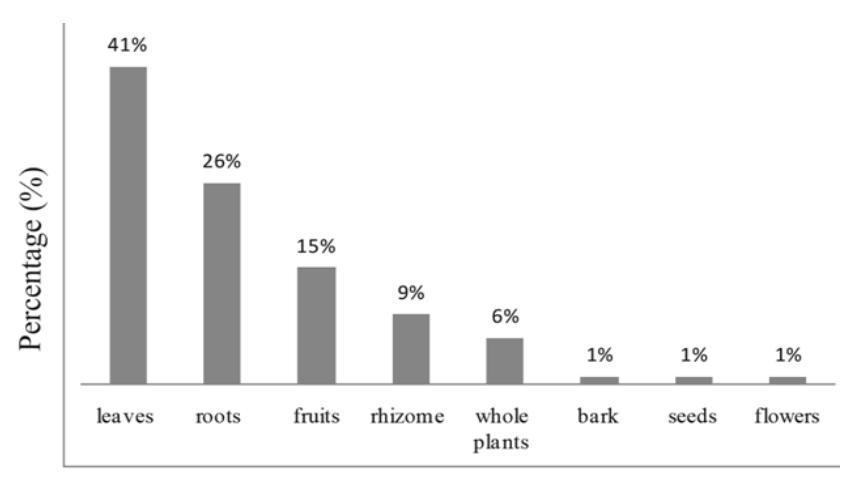

Part plants used to treat ailments

Figure 3. Parts of medicinal plants used to treat ailments 
Table 1. Diversity of plant species obtained in the home gardens of Kampung Masjid Ijok

\begin{tabular}{|c|c|c|c|c|c|c|c|}
\hline Species name & Family name & Local name & Habit & Part used & $\begin{array}{c}\text { Freq. of } \\
\text { occurrence }\end{array}$ & Use & $\begin{array}{l}\text { Preparation/ } \\
\text { administration }\end{array}$ \\
\hline Ageraratum conyzoides $\mathrm{L}$. & Asteraceae & Pokok tahi babi & Herb & Leaves & 1 & Treat colic, colds, and fevers & Infusion/ orally \\
\hline Allium tuberosum Rottler ex Spreng & Amaryllidaceae & Kucai & Herb & Leaves & 4 & Treating parasites in the intestines & Decoction/ orally \\
\hline Alpinia conchigera Griff & Zingiberaceae & Lengkuas ranting & Herb & Leaves & 10 & Rheumatism & Poultice/ dressing \\
\hline Ananas nanus L.B. & Bromeliaceae & Nanas batu & Shrub & Fruits & 2 & Kidney stones & Infusion/ orally \\
\hline Andrographis paniculata (Burm.f.) Wall. ex Nees & Acanthaceae & Hempedu bumi & Herb & Whole plants & 1 & Hypertensions & Decoction/ orally \\
\hline Annona muricata $\mathrm{L}$ & Annonaceae & Durian belanda & Tree & Leaves & 8 & Fever & Infusion/ dressing \\
\hline Areca catechu L. & Arecaceae & Pinang & Tree & Roots & 18 & Kidney stone & Decoction/ orally \\
\hline Barringtonia racemosa (L.) Spreng & Lecythidaceae & Putat & Tree & Fruits & 3 & Cough, asthma & Infusion/ orally \\
\hline Blumea balsamifera (L.) DC. & Asteraceae & Capa & Shrub & Leaves & 4 & Diarrhea & Decoction/ orally \\
\hline Carica papaya $\mathrm{L}$. & Caricaceae & Betik & Herb & Fruits & 26 & Constipation & Infusion/ orally \\
\hline Cassia tora $(\mathrm{L}$.$) Roxb$ & Fabaceae & Geleng-gang kecil & Herb & Roots & 2 & Kidney stones & Decoction/ orally \\
\hline Centella asiatica (L.) Urban & Mackinlayaceae & Pegaga & Herb & Whole plants & 2 & Aging & Infusion/ orally \\
\hline Chassalia curviflora (Wallich) Thwaites & Rubiaceae & Beberas & Shrub & Roots & 3 & Coughs & Decoction/ orally \\
\hline Citrus aurantiifolia (Chris. \& Panz.) Swin & Rutaceae & Limau nipis & Tree & Fruits & 15 & Dysmenorrhea & Infusion/ orally \\
\hline Clerodendron paniculatum L. & Lamiaceae & Pepanggil & Shrub & Roots & 2 & Asthma & Decoction/ orally \\
\hline Clidemia hirta (L.) D. Don & Melastomataceae & Senduduk babi & Shrub & Roots & 7 & Poison antidote & Decoction/ orally \\
\hline Clinacanthus nutans (Burm F.) Lindau & Acanthaceae & Belalai gajah & Shrub & Leaves & 3 & Gastrointestinal disorders & Decoction/ orally \\
\hline Cocos nucifera $\mathrm{L}$. & Arecaceae & Kelapa & Tree & Roots & 28 & Kidney stone & Decoction/ orally \\
\hline Coleus blumei Benth & Lamiaceae & Ati-ati & Herb & Leaves & 6 & Diarrhea & Poultice/ dressing \\
\hline Curcuma aeruginosa Roxb & Zingiberaceae & Kunyit hitam & Herb & Rhizome & 2 & Cough and asthma & Decoction/ orally \\
\hline Cymbopogon flexuosus (Nees ex Steud.) & Gramineae & Serai hitam & Herb & Roots & 1 & Indigestion & Decoction/ orally \\
\hline Cyperus alternifolius $\mathrm{L}$. & Cyperaceae & Nerung & Shrub & Roots & 3 & Kidney stones & Decoction/ orally \\
\hline Dioscorea hispida Dennst. & Dioscoreaceae & Ubi gadut & Herb & Rhizome & 1 & Sore feet & Poultice/ dressing \\
\hline Elettariopsis slahmong C.K. Lim_ & Zingiberaceae & Halia kesing & Herb & Leaves & 4 & Treat post-partum & Poultice/ dressing \\
\hline Euphorbia hirta $\mathrm{L}$ & Euphorbiaceae & Ara tanah & Herb & Whole plants & 1 & Gastrointestinal disorders & Decoction/ orally \\
\hline Eurycoma longifolia Jack & Simaroubaceae & Tongkat ali & Tree & Roots & 4 & Low sexual energy & Decoction/ orally \\
\hline Ficus deltoidea Jack & Moraceae & Mas cotek & Shrub & Leaves & 1 & Hypertension & Decoction/ orally \\
\hline Ficus obpyramidata Miq & Moraceae & Kelempung & Tree & Fruits & 3 & $\begin{array}{l}\text { Galactagogue (promotes lactation in } \\
\text { human) }\end{array}$ & Eaten raw/orally \\
\hline Garcinia atroviridis Griff. ex T. Anders & Clusiaceae & Gelugur & Tree & Fruits & 4 & Hypertension & Decoction/ orally \\
\hline Gynura sarmentosa DC & Asteraceae & Sambung nyawa & Herb & Leaves & 1 & Dysentry & Decoction/ orally \\
\hline Hibiscus rosa-sinensis L. & Malvaceae & Bunga raya & Shrub & Leaves & 10 & Fever & Infusion/ dressing \\
\hline Kaempferia galanga $\mathrm{L}$ & Zingiberaceae & Cekur & Herb & Leaves & 2 & Womb healing after childbirth & Decoction/ orally \\
\hline Kalanchoe pinnata (Lamk.) Pers & Crassulaceae & Setawar & Herb & Leaves & 3 & Headache & Poultice/ dressing \\
\hline Leucaena leucocephala (Lamk) De Wit. & Leguminosae & Petai belalang & Tree & Seeds & 4 & $\begin{array}{l}\text { Stomachache, contraception, } \\
\text { abortifacient }\end{array}$ & Infusion/ orally \\
\hline
\end{tabular}




\begin{tabular}{|c|c|c|c|c|c|c|c|}
\hline Mallotus barbatus Müll.Arg & Euphorbiaceae & Pokok tapu & Tree & Roots & 2 & Gastrointestinal disorders & Decoction/ orally \\
\hline Mangifera foetida Lour & Anacardiaceae & Machang & Tree & Leaves & 7 & Skin complaints & Poultice/dressing \\
\hline Maranta arundinacea $\mathrm{L}$. & Marantaceae & Ubi larut & Herb & Roots & 2 & Poison antidote & Decoction/ orally \\
\hline Melastoma decemfidum Roxb. ex Jack. & Melastomataceae & Senduduk & Shrub & Roots & 6 & Kidney stones & Decoction/ orally \\
\hline Mimosa pudica $\mathrm{L}$ & Fabaceae & Semalu & Herb & Whole plants & 1 & Athlete's foot & Poultice/ dressing \\
\hline Mikania micrantha Kunth ex H.B.K & Asteraceae & Selaput tunggul & Climber & Leaves & 3 & Stop minor external bleeding & Poultice/dressing \\
\hline Molineria latifolia (Dryand. ex W.T.Aiton) & Asteraceae & Remba & Herb & Roots & 5 & Menorrhagia & Decoction/ orally \\
\hline Morinda citrifolia $\mathrm{L}$. & Rubiaceae & Mengkudu & Tree & Leaves & 6 & Treat post-partum & Poultice/ dressing \\
\hline Nepenthes gracilis Korth & Nepenthaceae & Periuk kera & Herb & Roots & 1 & Dysentry & Decoction/ orally \\
\hline Ocimum sanctum $\mathrm{L}$ & Lamiaceae & Selasih & Herb & Leaves & 2 & Coughs & Decoction/ orally \\
\hline Oroxylum Indicum Vent. & Bignoniaceae & Beka & Tree & Leaves & 12 & Fever & Poultice/dressing \\
\hline Orthosiphon aristatus (BI.) Miq & Lamiaceae & Misai kucing & Shrub & Leaves & 2 & Diabetes & Decoction/ orally \\
\hline Oxalis barrelieri $\mathrm{L}$. & Oxalidaceae & Belimbing tanah & Herb & Roots & 3 & Hypertension & Decoction/ orally \\
\hline Pandanus atrocarpus Griff & Pandanaceae & Mengkuang & Shrub & Roots & 3 & Kidney stones & Decoction/ orally \\
\hline Parkia speciosa Hassk. & Mimosaceae & Petai & Tree & Fruits & 13 & Diabetes & Infusion/ orally \\
\hline Passiflora edulis Sims & Passifloraceae & Markisa & Climber & Flowers & 1 & Gastrointestinal disorders & Infusion/ orally \\
\hline Physalis minima $\mathrm{L}$ & Solanaceae & Letup-letup & Herb & Leaves & 1 & Head-ache & Poultice/ dressing \\
\hline Piper betle $\mathrm{L}$. & Piperaceae & Sirih & Herb & Leaves & 10 & Stop internal bleeding in the nose & Poultice/dressing \\
\hline Piper sarmentosum Roxb. Ex hunt & Piperaceae & Kadok & Herb & Roots & 11 & Cough, asthma & Decoction/ orally \\
\hline Psidium guajava $\mathrm{L}$ & Myrtaceae & Jambu biji & Tree & Leaves & 3 & Diarrhea, stomach-ache & Infusion/ orally \\
\hline Phyllanthus pulcher Wall. ex Müll. Arg & Euphorbiaceae & Naga buana & Shrub & Leaves & 1 & Boils, carbuncles & Poultice/dressing \\
\hline Ricinus communis $\mathrm{L}$ & Euphorbiaceae & Pokok jarak & Shrub & Leaves & 1 & Rheumatism & Poultice/ dressing \\
\hline Rhinacanthus communis (L.) Kurz & Acanthaceae & Ubat kurap & Shrub & Leaves & 1 & Skin complaints & Poultice/ dressing \\
\hline Scorodocarpus borneensis (Baill.) Becc & Olacaceae & Kulim & Tree & Fruits & 8 & Indigestion & Infusion/ orally \\
\hline Sida rhombifolia $\mathrm{L}$ & Malvaceae & Senanguri & Shrub & Roots & 1 & Fever & Decoction/ orally \\
\hline Solanum torvum Swar. & Solanaceae & Terung ceweng & Shrub & Fruits & 6 & Hypertension & Infusion/ orally \\
\hline Stachytarpheta jamaicensis (L.) Vahl & Verbenaceae & Cabai tali & Shrub & Leaves & 3 & Scabies, abscess & Poultice/dressing \\
\hline Tacca integrifolia Ker Gawler & Dioscoreaceae & Keladi murai & Shrub & Rhizome & 1 & Skin complaints & Poultice/ dressing \\
\hline Tamarindus Indica $\mathrm{L}$ & Fabaceae & Asam jawa & Tree & Fruits & 1 & Fever, sore throat & Juice/ orally \\
\hline Typhonium flagelliforme (Lodd) Blume & Araceae & Keladi tikus & Herb & Rhizome & 1 & $\begin{array}{l}\text { Expectorant for respiratory disorders } \\
\text { (cough/asthma) }\end{array}$ & Infusion/ orally \\
\hline Vernonia amygdalina Del & Asteraceae & Ketum cina & Shrub & Leaves & 4 & Treatment of jaundice, diarrhea & Decoction/ orally \\
\hline Vitex pubescens Vahl & Verbenaceae & Halban & Tree & Bark & 1 & Womb healing after childbirth & Decoction/ orally \\
\hline Zingiber officinale Roscoe & Zingiberaceae & Halia & Herb & Rhizome & 7 & Flatulence & Decoction/ orally \\
\hline Zingiber aromaticum Vahl & Zingiberaceae & Lempoyang & Herb & Rhizome & 3 & Worm infestation in children & Decoction/ orally \\
\hline
\end{tabular}


Similarly, medicinal uses of Psidium guajava have also been reported in previous ethnobotanical studies in other countries. For example, Tangjitman et al. (2015) and Jadid et al. (2020) reported the use of Psidium guajava to treat diarrhea by the Karen community of Northern Thailand, and the Tengger tribe in Ngadisari village of Indonesia respectively. The main administration routes of the remedies were taken orally $(72 \%)$ and topical application $(28 \%)$. The most common methods of preparation were decoction $(50 \%)$, poultice $(25 \%)$, and infusion $(25 \%)$. Oral ingestion through the decoction method is the simplest way to take medicine. This method is applied to treat ailments by the most local community based on the previous ethnobotanical studies such as by the Tengger tribe in Indonesia (Jadid et al. 2020), the Karen tribe in Thailand (Tangjitman et al. 2015), the Jakun tribe in Malaysia (Sabran et al. 2016), and the Mulam tribe in China (Hu et al. 2020). However, there are a few medicine derived from decoction, applied externally by bathing, such as treatment for postpartum among women. Some plant parts were crushed to release active compounds before being applied directly to affected organs to treat wounds or inflammation.

In conclusion, the home gardens of Kampung Masjid Ijok, with their diverse medicinal plant collection, serve as important reservoirs for medicinal plant species and traditional knowledge. The knowledge is still practiced and disseminated among family members, and this makes the home gardens one of the important places to study ethnopharmacology. Medicinal plants in home gardens are used mostly to treat ailments in the categories of gastrointestinal disorders and respiratory issues. These are the most common health issues in rural areas. Thus, the findings of this study can be an important factor in the selection of medicinal plants to be planted and cared for in the home gardens.

\section{ACKNOWLEDGEMENTS}

We thank the University of Malaya and the Ministry of Education of Malaysia for providing facilities and funds that enable this study to be carried out. This study was funded by PG072-2013A, RF193-12SUS, and LL02316SUS provided by the University of Malaya, and MyBrain 15 Scholarship provided by the Ministry of Education of Malaysia. This study is also to be a part of a Ph.D. contribution of the first author.

\section{REFERENCES}

Abebe T, Sterck FJ, Wiersum KF, Bongers F. 2013. Diversity, composition, and density of trees and shrubs in agroforestry homegardens in Southern Ethiopia. Agrofor Syst 87 (6): 1283-1293. DOI: $10.1007 / \mathrm{s} 10457-013-9637-6$

Aziz SHA, Zakaria Z. 2013. The diversity of medicinal plant resources in Kampung Batu Ring-Kampung Beng: a case study of Lenggong Valley, World Heritage Site. In: Mohamed B, Bahauddin A (eds) Building the Future of Tourism: Proceedings of International Conference on Tourism Development, Malaysia.
Azliza M, Ong H, Vikineswary S, Noorlidah A, Haron N. 2012. Ethnomedicinal resources used by the Temuan in Ulu Kuang Village. Stud Ethno-Med 6 (1): 17-22. DOI: 10.1080/09735070.2012.11886415

Bhat S, Bhandary MJ, Rajanna L. 2014. Plant diversity in the homegardens of Karwar, Karnataka, India. Biodiversitas 15 (2): 229235. DOI: $10.13057 /$ biodiv/d150216

Cruz-Garcia GS, Struik PC. 2015. Spatial and seasonal diversity of wild food plants in home gardens of Northeast Thailand. Econ Bot 69 (2): 99-113. DOI: $10.1007 / \mathrm{s} 12231-015-9309-8$

Eyasu G, Tolera M, Negash M. 2020. Woody species composition, structure, and diversity of homegarden agroforestry systems in southern Tigray, Northern Ethiopia. Heliyon 6 (12): e05500. DOI: 10.1016/j.heliyon.2020.e05500

Gao J, He T, Li QM. 2012. Traditional home-garden conserving genetic diversity: a case study of Acacia pennata in southwest China. Conserv Genet 13 (4): 891-898. DOI: 10.1007/s10592-012-0338-X

Hu R, Lin C, Xu W, Lui Y, Long C. 2020. Ethnobotanical study on medicinal plants used by Mulam people in Guangxi, China. J Ethnobiol Ethnomed 16 (40): 1-50. DOI: 10.1186/s13002-020-00387-

Huai H, Xu W, Wen G, Bai W. 2011. Comparison of the Homegardens of Eight Cultural Groups in Jinping County, Southwest China. Econ Bot 65 (4): 345-355. DOI: 10.1007/s12231-011-9172-1

Hussain AG, Normah MN, Hussin K. 2015. Nature's Medicine: A collection of Medicinal Plants from Malaysia's Rainforest, Volume 1. Landskap Malaysia, Malaysia.

Jadid N, Kurniawan E, Himayani CES, Andriyani, Prasetyowati I, Purwani KI, Muslihatin W, Hidayati D, Tjahjaningrum ITD. 2020. An ethnobotanical study of medicinal plants used by the Tengger tribe in Ngadisari village, Indonesia. PLoS One 15 (7). DOI: 10.1371/journal.pone.0235886.

Mapongmetsem PM, Nkongmeneck BA, Gubbuk H. 2012. Socioeconomic importance of the banana tree (Musa spp.) in the Guinean Highland Savannah agroforests. Sci World J 2012: 350258. DOI: $10.1100 / 2012 / 350258$.

Mattsson E, Ostwald M, Nissanka SP, Pushpakumara DKNG. 2015. Quantification of carbon stock and tree diversity of homegardens in a dry zone area of Moneragala district, Sri Lanka. Agrofor Syst 89 (3): 435-445. DOI: 10.1007/s10457-014-9780-8

Milow P, Malek S, Mohammad NS et al. 2013. Diversity of plants tended or cultivated in Orang Asli homegardens in Negeri Sembilan, Peninsular Malaysia. Hum Ecol 41 (2): 325-331. DOI: 10.1007/s10745-012-9555-7.

Mohammad NS, Milow P, Ong HC. 2012. Traditional Medicinal Plants Used by the Kensiu Tribe of Lubuk Ulu Legong, Kedah, Malaysia. Ethno Med 6 (3): 149-153. DOI: 10.1080/09735070.2012.11886432

Ong HC, Faezah AW, Milow P. 2012a. Medicinal plants used by the Jah Hut Orang Asli at Kampung Pos Penderas, Pahang, Malaysia. Ethno Med 6 (1): 11-15. DOI: 10.1080/09735070.2012.11886414.

Ong HC, Lina E, Milow P. 2012b. Traditional knowledge and usage of medicinal plants among the Semai Orang Asli at Kampung Batu 16, Tapah, Perak, Malaysia. Ethno Med 6 (3): 207- 211. DOI: 10.1080/09735070.2012.11886440.

Ong HC, Rosnaini MZ, Pozi M 2011a. Traditional Knowledge of Medicinal Plants among the Malay Villagers in Kampung Mak Kemas, Terengganu, Malaysia. Etho Med 5 (3): 175-185. DOI: 10.1080/09735070.2011.11886407.

Ong HC, Ruzalila BN, Pozi M. 2011b. Traditional knowledge of medicinal plants among the Malay villagers in Kampung Tanjung Sabtu, Terengganu, Malaysia. Indian J Tradit Knowl 10 (3): 460-465. DOI: $10.1080 / 09735070.2011 .11886407$.

Pala NA, Sarkar BC, Shukla G, Chettri N, Deb S, Bhat JA, Chakravarty S. 2019. Floristic composition and utilization of ethnomedicinal plant species in home gardens of the Eastern Himalaya. J Ethnobiol Ethnomed 15 (1): 1-16. DOI: 10.1186/s13002-019-0293-4.

Panyadee P, Balslev H, Wangpakapattanawong P, Inta A. 2019. Medicinal plants in homegardens of four ethnic groups in Thailand. J Ethnopharmacol 239: 111927. DOI: 10.1016/j.jep.2019.111927.

Pimm S, Russell G, Gittleman J, Brooks T. 1995. The future of biodiversity. $\quad$ Science 269 (5222): 347-350 DOI: 10.1126/science.269.5222.34.

Quave CL, Pieroni A. 2015. A reservoir of ethnobotanical knowledge informs resilient food security and health strategies in the Balkans. Nat Plants 1 (2): 1-6. DOI: 10.1038/nplants.2014.21. 
Rahman SA, Baldauf C, Mollee EM, Abdullah-Al-Pavel M, Abdullah-AlMamum Md, Toy MM, Sunderland T. 2013. Cultivated plants in the diversified homegardens of local communities in Ganges Valley, Bangladesh. Sci J Agric Res Manag. DOI: 10.7237/sjarm/197.

Ramli MR, Malek S, Milow P, Aziz NJ. 2021. Traditional knowledge of medicinal plants in Kampung Orang Asli Donglai Baru, Hulu Langat, Malaysia. Biodiversitas $22 \quad$ (3): 1304-1309. DOI 10.13057/biodiv/d220329.

Sabran ST, Mohamed M, Bakar MFA. 2016. Ethnomedical knowledge of plants used for the treatment of Tuberculosis in Johor, Malaysia. Evidence-Based Complement Altern Med 2016: 2850845. DOI: $10.1155 / 2016 / 2850845$.

Saynes-Vásquez A, Caballero J, Meave JA, Chiang F. 2013. Cultural change and loss of ethnoecological knowledge among the Isthmus Zapotecs of Mexico. J Ethnobiol Ethnomed 9 (40): 1-10. DOI: 10.1186/1746-4269-9-40

Srithi K, Trisonthi C, Wangpakapattanawong P, Srisangka P, Balslev H. 2012. Plant diversity in Hmong and Mien homegardens in northern
Thailand. Econ Bot 66 (2): 192-206. DOI: 10.1007/s12231-012-9199y.

Tangjitman K, Wongsawad C, Kamwong K, Sukkho T, Trisonthi C. 2015. Ethnomedicinal plants used for digestive system disorders by the Karen of Northern Thailand. J Ethnobiol Ethnomed 11 (1): 1-13. DOI: $10.1186 / \mathrm{s} 13002-015-0011-9$.

Wezel A, Ohl J. 2005. Does remoteness from urban centres influence plant diversity in homegardens and Swidden fields?: A case study from the Matsiguenka in the Amazonian rain forest of Peru. Agrofor Syst 65 (3): 241-251. DOI: 10.1007/s10457-005-3649-9.

Wiehle M, Goenster S, Gebauer J, Mohamed SA, Buerkert A, Kehlenbeck K. 2014. Effects of transformation processes on plant species richness and diversity in homegardens of the Nuba Mountains, Sudan. Agrofor Syst 88 (3): 539-562. DOI: 10.1007/s10457-014-9717-2.

Zaki PH, Gandaseca S, Rashidi NM, Ismail MH. 2019. Traditional usage of medicinal plants by Temiar tribes in the state of Kelantan, Peninsular Malaysia. For Soc 3 (2): 227-234. DOI: $10.24259 /$ fs.v3i2.6424. 